\title{
THE CEA: FROM STABILIZATION TO RESOURCE ALLOCATION
}

\author{
Martin Feldstein
}

Working Paper 5908

\author{
NATIONAL BUREAU OF ECONOMIC RESEARCH \\ 1050 Massachusetts Avenue \\ Cambridge, MA 02138 \\ January 1997
}

Professor of Economics, Harvard University, and President of the National Bureau of Economic Research, 1050 Massachusetts Avenue, Cambridge, MA 02138 (msfeldst@nber.org). This paper was presented at the 1997 annual meeting of the American Economic Association. This paper is part of NBER's research programs in Monetary Economics and Public Economics. Any opinions expressed are those of the author and not those of the National Bureau of Economic Research.

(C) 1997 by Martin Feldstein. All rights reserved. Short sections of text, not to exceed two paragraphs, may be quoted without explicit permission provided that full credit, including $\mathbb{C}$ notice, is given to the source. 
The CEA: From Stabilization to Resource Allocation Martin Feldstein

NBER Working Paper No. 5908

January 1997

JEL No. A11

Monetary Economics and Public Economics

\begin{abstract}
This paper traces the changing role of the Council of Economic Advisers. In the 50 years since its creation, the CEA's focus has shifted from the design of policies to achieve full employment to one of advising on the much-enlarged spending and tax activities of the federal government. The CEA's original attention to achieving cyclical stability through fiscal policy diminished as economists changed their views about the inherent stability of the economy and the usefulness of fiscal policy. With the shift of macroeconomic policy to the Federal Reserve, the CEA's macroeconomic role has diminished but not disappeared. The rapid growth of government spending during the past five decades has greatly increased the role for the CEA in seeking efficient resource allocation.
\end{abstract}

Martin Feldstein

President

National Bureau of Economic Research

1050 Massachusetts Avenue

Cambridge, MA 02138

msfeldst@nber.org 


\title{
The CEA: From Stabilization to Resource Allocation
}

\author{
Martin Feldstein*
}

The Council of Economic Advisers was conceived in a spirit of good will, but was based on two false economic premises that have made its original mission both impossible and irrelevant. That the Council has now survived for 50 years and continues to play a central role in successive administrations reflects its ability to adapt to the revolution that has occurred in economic thinking and to the changing nature of our national government. ${ }^{1}$

The worldview of the leading economic thinkers when the CEA was created in 1946 can be summarized as "macroeconomic instability and microeconomic insensitivity." Their presumption that the economy is inherently unstable and prone to major business cycles and deep depressions implied an important role for active demand management through fiscal policy. Their view that individuals do not alter their behavior in response to high marginal tax rates or generous transfer payments implied that the government could achieve whatever distribution of income was desired and could provide protection against the various risks of economic life without adverse effects on individual behavior.

${ }^{1}$ I have written more generally about the role of the CEA and about my own experience as CEA chairman in 1982-84 in Feldstein (1989, 1992, 1993 and 1995).

* Professor of Economics, Harvard University, and President of the National Bureau of Economic Research. 1050 Massachusetts Avenue, Cambridge, MA 02138 (msfeldst@nber.org). This paper was presented at the 1997 annual meeting of the American Economic Association.

cea.aea 
Today, for most economists, that worldview has been reversed. The macroeconomy appears more stable while demand management, especially through fiscal policy, is viewed with suspicion as more likely to be destabilizing than stabilizing. Responsibility for macroeconomic stabilization policy has therefore effectively shifted to the Federal Reserve. Individuals are now perceived to be quite sensitive to the high marginal tax rates that are explicit in the tax laws and implicit in the transfer programs that now account for the bulk of government spending.

The past 50 years have also witnessed an enormous expansion of the role of the government in the domestic economy. Back in 1946, federal government spending on all domestic programs (i.e., all government spending other than defense, international affairs and net interest) totaled only $\$ 6.6$ billion or three percent of GDP! Fifty years later, federal government domestic spending exceeds $\$ 1$ trillion and has reached nearly 14 percent of GDP.

In light of all of this, the appropriate role of the CEA has therefore shifted from the design of policies to achieve macroeconomic stability and full employment to one of advising on ways to serve the many purposes now assumed by the federal government and to do so in ways that reduce the resulting adverse effects on individual incentives. Before talking about some of the difficulties of this new role, I want to look in more detail at the shift away from stabilization as the primary concern of the CEA that has occurred since its creation.

I. The Shifting Locus of Stabilization Policy

Fifty years ago, when the Employment Act of 1946 that created the CEA was signed by 
President Truman ${ }^{2}$, there was a widespread fear that the end of World War II would plunge the economy back into the terrible depression conditions of the prewar years. The basic facts were certainly enough to frighten any noneconomist. Government spending, which accounted for 44 percent of GDP in 1945, was about to decline by nearly two thirds in the next two years. The budget went from a deficit of 22 percent of GDP in 1945 to a surplus two years later.

Demobilization increased the civilian population by 9 million persons between 1945 and 1946, equivalent to one-sixth of the civilian labor force. To economists, these conditions were compounded by the new message of Keynesian economics emphasizing the possibility that, even after the transition to a peacetime economy, the desired saving rate would be persistently too high to be compatible with full employment.

The early postwar experience appeared to bear out these fears. Real GDP fell sharply in 1946 and did not reach its peak wartime level until 1951 in the midst of the Korean war. Fortunately, the experience of the 1950 s then showed that the economy could operate at low unemployment rates without large budget deficits or a high level of government spending; the unemployment rate averaged 4.5 percent during the 1950 s while the budget deficits averaged less than 0.5 percent of GDP.

The 1950s also saw a gradual shift from a focus on employment as the only goal of macroeconomic policy to a consideration of inflation as well as unemployment. The Phillips

${ }^{2}$ Economists who recall President Truman's famous statement that he wished he had a one-handed economist might wonder what he thought about his Council of Economic Advisers. At that time, the three man Council could speak to the President with three different voices. It was President Eisenhower who signed the executive order vesting all of the authority of the Council in the Chairman. This executive order still stands so that the Chairman alone is responsible for all of the opinions and testimony given in the name of the Council. 
curve, published in 1958, appeared to provide a framework for trading between permanently higher inflation and permanently lower unemployment. Within this intellectual framework, the CEA could advise President Kennedy on the desirability of expansionary fiscal policy and on the appropriate magnitude of the fiscal stimulus.

But the experience of the 1960s and 1970s led the economics profession to a thoroughgoing rejection of both the Phillips curve framework and of its earlier faith in the usefulness of fiscal policy. The notion of a long-run Phillips curve was rejected for both empirical and theoretical reasons. Higher inflation in the 1970s than the 1960s was accompanied by higher rather than lower rates of unemployment; the unemployment rate rose from 4.8 percent in the $1960 \mathrm{~s}$ to 6.2 percent in the 1970 s while inflation rose from 2.3 percent to 7.1 percent. Milton Friedman persuaded the profession that the long-run Phillips curve was based on a confusion of real and nominal magnitudes and that the long-run rate of inflation must be independent of the rate of unemployment. The profession's faith in fiscal stabilization policy was eroded as empirical research diminished the estimated fiscal multiplier by taking into account relatively inelastic money demand, endogenous price responses, and leakages through foreign trade. A shift from a comparative static analysis to a dynamic framework also made it clear that lags in the impact of fiscal policy were very important and that the length of those lags was very uncertain, making it easy for fiscal policy to add its expansionary impact long after the trough of the recession and therefore to be destabilizing rather than stabilizing.

The decline in the perceived usefulness of fiscal policy was accompanied by an increased respect for monetary policy. Unlike the earlier Keynesian belief that monetary policy was ineffective, the new view recognized the power of money in the inflation process and the 
potentially useful role of monetary policy in short-run stabilization. Monetary policy was seen as both more powerful and more flexible because it could be adjusted quickly by the Federal Reserve Open Market committee without the cumbersome political process that delayed changes in fiscal policy.

This shift from fiscal policy to monetary policy changed the role of the CEA in a very fundamental way. The Federal Reserve is an independent agency that is not subject to control by either the President or the Congress. With all of the key decisions about macroeconomic stabilization policy being made by the Federal Reserve, the CEA would in principle no longer have any role to play in macroeconomic stabilization policy.

In principle, but not in fact. Experience shows that the Federal Reserve cannot exercise its full legal power to contract demand or to limit an economic expansion if that action is strongly opposed by the Congress or by the President. President Carter effectively forced the Federal Reserve to reverse its contractionary policy in 1980. From time to time, the Congress tries to force the Fed to soften its monetary policy by threatening to change the composition of the Federal Reserve Open Market Committee or the method by which its members are appointed in ways that would reduce the Fed's independence.

My experience during the Reagan years was that the President can protect the Fed's freedom of action by a show of personal support. Because monetary policy is a relatively arcane subject, it is typically only the Treasury and the Council of Economic Advisers that can presume to advise the President on these matters. The CEA can therefore play a useful even if only indirect role in macroeconomic policy by helping the President to assess the Federal Reserve's current policy and by urging Presidential support when it is appropriate. 
Because of the current economic situation, the Federal Reserve may well raise interest rates in 1997. If it does so, the Fed's aim would be to slow the rate of growth and increase the level of unemployment in order to reverse a rise in the rate of inflation and to move the economy closer to price stability. As the unemployment rate begins to rise, the critics of the Fed will undoubtedly call for lower interest rates and a more expansionary monetary policy. It will be the difficult task of the CEA chairman to explain that a temporary period of unemployment above the long-run natural rate is a desirable policy that will be rewarded with a permanently lower rate of inflation.

\section{Improving the Allocation of Economic Resources}

Although the past fifty years have seen a sharp reduction in the role of the CEA in guiding discretionary stabilization policy, the enormous growth of domestic government activities during those same years has created an important new role for the CEA in improving the efficiency of resource allocation. Although there are many good economists in the individual government departments, it is the CEA that can best represent the interest of the general public and of future generations. It is not surprising that the economists in the agriculture department are more likely to consider the well-being of farmers than of consumers. Or that the economists in the Commerce Department favor the interests of businesses over consumers. And while the Treasury staff does not have a similar constituency bias, the Treasury's process of estimating tax revenue is based on a long-standing, but inappropriate method that assumes that taxes do not alter the supplies of labor and capital and that appears to substantially underestimate the adverse effect of higher tax rates on taxable income and economic efficiency (Feldstein, 1996). Finally, 
although the Office of Management and Budget is generally close to the CEA in its analysis of individual programs, it is likely to favor program designs that reduce government spending and budget deficits even if doing so distorts incentives and creates a larger excess burden than would otherwise be necessary. So it is the CEA that must represent economic efficiency.

Unfortunately, policies to increase economic welfare and reduce excess burdens are far more difficult to explain to senior government officials and to the Congress than policies that lead to more tangible effects on employment and GDP.

Just think about the difficulty of explaining that a policy change that removes a distortion is good even if it causes incomes to decline. The concepts of "excess burden" and "economic efficiency" that we as economists understand so well are very difficult to communicate in a persuasive way to someone who does not have the basic structure of economic ideas that we teach to undergraduates. As a teacher of the introductory economics course at Harvard, I often think how much better the world would be if the key decision makers in Washington understood the rudiments of welfare economics as well as the majority of my freshman students.

One of the primary sources of the persistence of bad program design is the assumption of "microeconomic insensitivity" that I mentioned at the beginning of these remarks. Many of the existing government programs as well as the proposals for new programs that are designed by non-economists make the implicit assumption that the program induces no change in individual behavior. Although economists are now likely to recognize the importance of behavioral responses, even many economists still underestimate the relevant response elasticities.

Three examples will illustrate my point. The first is the program of Social Security retirement benefits. In Washington those benefits are generally incorrectly analyzed as if they 
supplement private saving rather than substituting a low return unfunded benefit for private saving. My second example is the relatively recent expansion of the Medicaid program to children and pregnant women with higher incomes than the level that was previously eligible for Medicaid. A recent paper by David Cutler and Jonathan Gruber (1995) showed that threequarters of the newly covered group already had private insurance and that two-thirds of them gave up their private coverage when they became eligible for Medicaid.

As a final example, consider President Clinton's recent proposal to give a rebatable tax credit to offset some of the cost of the first two years of post-secondary school education. It looks to me as if those credits would generally not benefit the poor (because they are already eligible for other federal grants) but would frequently displace existing private scholarships and parental payments without leading to increased college attendance. The CEA can help to evaluate and perhaps redesign these policies by asking how much displacement is likely to occur and what the total cost, including the excess burden of tax collection, would be per additional enrolled student.

As these examples illustrate, an important task for the CEA is to point out the likely behavioral response to proposed policies and to evaluate the implications of that response for program costs and for the efficiency of the proposed policy. The CEA will face a formidable array of issues during 1997 and the years ahead. These will deal with the budget, trade policy, Medicare redesign, tax changes, and much more. In each case, the kind of analysis that the CEA does best can make an important contribution to good decision making.

Looking to the future, it is clear that the Council of Economic Advisers can play an enormously useful role in improving the efficiency of government decisions. The rationale for 
the CEA has thus changed completely since its creation 50 years ago, but the nation should be glad that this small, cost-effective group with direct access to the President is there to deliver sound economic analysis and good advice. 


\section{References}

Cutler, David and Jonathan Gruber. "Does Public Insurance Crowd Out Private Insurance," Quarterly Journal of Economics 1995.

Feldstein, Martin. "How the CEA Advises Presidents," Challenge, November-December 1989, pp. 51-55.

Feldstein, Martin. "The Council of Economic Advisers and Economic Advising in the United States," The Economic Journal, 102 (September 1992) pp. 1223-1234

Feldstein, Martin. American Economic Policy in the 1980s (Chicago: Chicago University Press, 1993)

Feldstein, Martin. "Don't Shoot the Economic Messenger," The Wall Street Journal, June 28, 1995.

Feldstein, Martin. "How Big Should Government Be?" NBER Working Paper No. 5868, December 1996 (Forthcoming in The National Tax Journal, 1997). 